\title{
Pengembangan Modul Berbasis STEM (Science, Technology, Engineering, and Mathematics) Pokok Bahasan Alat-Alat Optik dalam Pembelajaran IPA di SMP
}

\author{
Dinda Ainun Afwina ${ }^{1 \star}$, Pramudya Dwi A.P², Aris Singgih Budiarso ${ }^{3}$ \\ 1,2,3 Pendidikan IPA, Fakultas Keguruan dan IImu Pendidikan \\ Universitas Jember (UNEJ), Jawa Timur - Indonesia \\ *E-mail Penulis Korespondensi: dindaainun60@mail.com
}

\begin{abstract}
Abstrak
Permasalahan yang dihadapi siswa kelas VIII MTsN 4 Banyuwangi salah satunya adalah bahan ajar berupa modul yang digunakan kurang menarik dan berkarakter, dimana kemampuan pemecahan masalah siswa cenderung rendah dan sulit memahami materi di modul. Penelitian ini bertujuan untuk mengembangkan modul IPA berbasis STEM yang layak dan menarik. Metode penelitian yang digunakan menggunakan jenis penelitian Research and development (R\&D) dengan menerapkan model pengembangan Nieveen. Subjek dari penelitian ini adalah kelas VIII B MTsN 4 Banyuwangi tahun ajaran 2020/2021 yang berjumlah 32 orang. Pengumpulan data penelitian melalui teknik validasi oleh ahli melalui lembar validasi dan angket respon siswa. Data yang diperoleh dianalisis secara deskriptif. Hasil penelitian menunjukkan bahwa modul IPA berbasis STEM termasuk kategori sangat valid dengan tingkat kevaliditan $92.5 \%$ dan memperoleh skor $\mathrm{N}$ - gain 0.42 yang menunjukkan kategori sedang sesuai dengan kriteria keefektifan modul, serta berdasarkan respon siswa memperoleh skor rata-rata pernyataan positif sebesar 3.27 yang termasuk kategori baik dan pernyataan negatif 1.82 yang termasuk kategori tidak baik.
\end{abstract}

Kata kunci: Alat-alat optik, modul, STEM

\section{Abstract}

One of the problems faced by class VIII MTsN 4 Banyuwangi is the use of unattractive and characterless learning modules. Students tend to be lo in improving problem-solving skills and have difficulty understanding the material in the modules. This research aims to develop a feasible and attractive STEM-based science module. This research used Research and development (R\&D) method by applying the Nieveen model. The subject of this research is class VIII B MTsN 4 Banyuwangi for the academic year 2020/2021, which consists of 32 students. Research data collection through validation techniques by experts through validation sheets and student response questionnaires. The data obtained were analyzed descriptively. Based on the module effectiveness criteria, the result of the study indicated that the effectivity of the developed STEM-based science module was in moderate criteria with a validity level of $92.5 \%$ and $\mathrm{N}$-gain score of 0.42 . The average score of students' positive statements is 3.27 (good category) and 1.82 (not good category) for negative statements.

Keywords: Optical tools, module, STEM

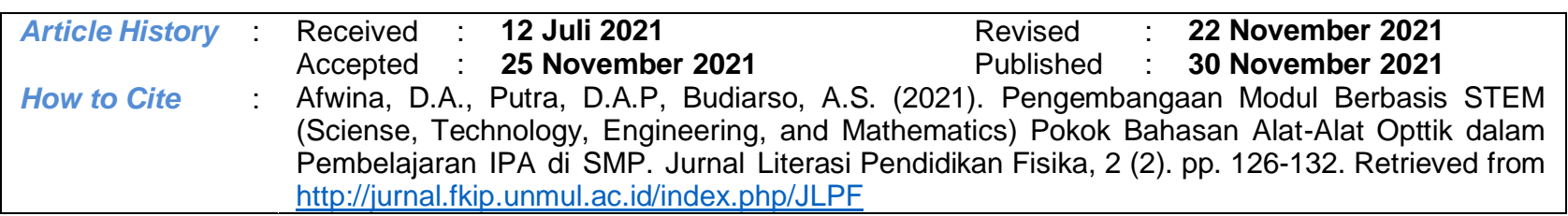

Copyright (c) November 2021, Jurnal Literasi Pendidikan Fisika 
Pengembangan Modul Berbasis ...

\section{PENDAHULUAN}

Pendidikan di Indonesia selalu mengalami perubahan kurikulum. Salah satu usaha yang dilakukan pemerintah untuk memajukan pendidikan di Indonesia adalah dengan menerapkan kurikulum 2013. Kurikulum 2013 sekolah menengah pertama/madrasah tsanaiyah, pada pembelajan IPA memiliki tujuan menekankan pada pengalaman sisa tentang lingkungan dan alam sekitar menggunakan metode ilmiah. Agar tujuan pembelajaran tercapai maka faktor yang dapat mempengaruhi yaitu sumber belajar yang digunakan saat proses pembelajaran (Tjiptiany et al, 2016). Pembelajaran IPA merupakan suatu pembelajaran yang mampu melibatkan siswa dalam memperoleh pengalaman secara langsung, kontekstual dan berpusat pada siswa, sehingga siswa dapat menemukan sendiri berbagai konsep dengan menyeluruh yang berkaitan dengan mata pelajaran IPA (Puskur, 2007). Permendiknas Nomor 22 tahun 2006 tentang standar isi menyatakan bahwa tujuan pembelajaran IPA yaitu memperoleh kompetensi dasar ilmu pengetahuan dan teknologi, membudayakan berpikir ilmiah, serta mampu belajar secara mandiri.

Menurut Nasution (2005) modul adalah unit lengkap yang terdiri atas rangkaian kegiatan belajar untuk membantu siswa belajar mandiri dalam mencapai tujuan yang telah dirumuskan secara khusus dan jelas. Depdiknas (2008) menyatakan baha tujuan dari dikembangkannya suatu modul adalah untuk meningkatkan tingkat efektivitas dan efisiensi pembelajaran, selain itu siswa dapat belajar dengan tuntas, siswa lebih aktif dalam belajar dengan membaca, melakukan kegiatan, dan memecahkan soal dengan materi sehingga siswa akan lebih aktif karena pembelajaran tidak sepenuhnya bergantung kepada guru.

Namun faktanya, berdasarkan hasil observasi dilapangan memuat pernyataan bahwa belum terdapat bahan ajar modul yang menarik dan berkarakter serta modul yang digunakan belum berorientasi pada pendekatan multi disiplin yaitu konsep materi yang diajarkan disesuaikan dan digabungkan dengan kehidupan dunia nyata berdarkan perkembangan teknolohgi. Sedangkan menurut Vellalba (dalam ardani et al, 2017) menyebutkan bahwa kurikulum 2013 menekankan siswa dapat menyelesaikan problematika kehidupan sehari-hari. Dengan menyelesaikan masalah tersebut siswa akan cenderung meningkatkan kemampuan pemecahan masalah yang dihadapi dan membangun sebuah argument serta menghasilkan kesimpulan.

Pendekatan STEM merupakan suatu pendekatan pembelajaran yang digunakan pengajar dengan adanya sistematik tertentu untuk tercapainya tujuan pembelajaran yang diinginkan dalam bidang sains, teknologi, teknik, dan matematika. Modul berbasis STEM adalah modul yang memiliki ciri-ciri sintak dari pembelajaran STEM. Modul berbasis STEM memiliki tujuan untuk membuat siswa mengetahui hubungan antara pengetahuan yang dimiliki dengan penerapannya dalam kehidupan nyata yang bisa diketahui dengan membeca, mencatat, meneliti, serta melakukan penelitian ilmiah (Bybee dalam Retnowati et al, 2020).

Alat-alat optik merupakan materi IPA dalam kurikulum 2013 yang sulit dipahami oleh siswa. Pernyataan tersebut dibuktikan dengan penelitian yang dilakukan oleh Ainiyah (2018) yaitu siswa sulit memahami materi optik dan melakukan percobaan dalam penerapan kehidupan sehari-hari. Siswa masih menggunakan persamaan-persamaan matematis dalam mengerjakan soal-soal yang sifatnya penerapan kehidupan sehari-hari, padahal materi alat-alat optik sangat dekat sekali dengan aplikasinya dalam kehidupan sehari-hari (Taufiq et al, 2018).

Berdasarkan latar belakang dan identifikasi masalah, maka tujuan yang ingin dicapai dalam penelitian ini adalah mengetahui validitas modul IPA berbasis STEM pokok bahasan alat-alat optik, efektifitas modul IPA berbasis STEM pokok bahasan alat-alat optik di SMP, dan respon siswa terhadap modul IPA berbasis STEM pokok bahasan alat-alat optik.

\section{METODE}

Jenis penelitian yang digunakan berupa penelitian dan pengembangan atau sering disebut dengan $R \& D$ (research and development). Metode penelitian R\&D merupakan penelitian yang digunakan untuk memperoleh produk tertentu dan bertujuan untuk menguji keefektifan produk yang diperoleh (Sumarsi et al, 2018). Produk akhir dalam penelitian ini berupa modul IPA berbasis STEM pada materi alat-alat 
optik untuk kelas VIII SMP yang dimanfaatkan sebagai media belajar siswa secara individu melalui kegitan pembelajaran di kelas.

Tempat dan waktu penelitian dilaksanakan di MTsN 4 Banyuwangi pada tahun ajaran 2020/2021 di semester genap. Desain penelitian pengembangan dalam penelitian ini menggunakan prosedur pengembangan menurut Nieveen dalam Akker, dkk (2006). Langkah-langkah pengembangan pada model pengembangan Nieveen terdiri 3 tahap yang akan peneliti lakukan, yaitu sebagai berikut:

\section{Tahap Penelitian Awal (Preliminary Research)}

Pelaksanaan studi pendahuluan bertujuan untuk memperoleh informasi yang berkaitan dengan kebutuhan sekolah sebagai dasar pengembangan modul. Informasi terkait yang dimaksud meliputi sumber belajar dan hasil belajar yang diperoleh melalui proses wawancara peneliti dengan salah satu guru IPA MTsN 4 Banyuwangi.

\section{Tahap Desain (Prototyping Stage)}

Dalam hal ini dilakukan pemilihan bahan ajar yang sesuai dengan permsalahan yang terjadi dan memilih bahan ajar yang akan digunakan dalam proses pembelajaran serta dapat membantu guru dalam proses pembelajaran sehingga siswa dapat menguasai konsep yang diajarkan. Pada tahapan ini produk akhir yang dihasilkan berupa modul pembelajaran dan instrumen validasi untuk menilai kevalidan modul IPA berbasis STEM pokok bahasan alat-alat optik. Validasi produk dilakukan validator ahli yaitu dua dosen Pendidikan IPA FKIP dan satu guru mata pelajaran IPA MTsN 4 Banyuwangi.

\section{Tahap Penilaian (Assessment Stage)}

Pada tahap ini, peneliti melakukan uji coba terhadap produk yang telah divalidasi pada tahap sebelumnya. Uji coba modul dilakukan untuk mengetahui hasil belajar siswa dan respon sisa terhadap produk yang dikembangkan. Peneliti melakukan analisis data yang diperoleh untuk mengetahui tingkat efektivitas modul terhadap hasil belajar siswa dan berapa banyak siswa memberikan respon positif.

Penelitian ini menggunakan Teknik Analisa data deskriptif kuantitatif, yaitu menjelaskan hasil pengembangan produk berupa modul IPA berbasis STEM pokok bahasan alat-alat optik. Data yang diperoleh melalui lembar validasi ahli dan angket respon siswaberupa data ordinal. Karena itu, data tersebut terlebih dahulu diubah menjadi data interval, kemudian dianalisis untuk mengetahui validitas, efektifitas, dan respon siswa.

\section{Validasi Modul Pembelajaran}

Menghitung total nilai validasi oleh validator menggunakan Persamaan (1) berikut:

$$
V_{a h}=\frac{T_{s e}}{T_{s h}} \times 100 \%
$$

Dimana $V_{\text {ah }}$ adalah variabel ahli, $T_{\text {se }}$ adalah total skor empiris yang diperoleh, dan $T_{\text {sh }}$ adalh total skor maksimal (Akbar, 2013). Kemudian disesuaikan dengan kriteria penilaian validitas seperti pada Tabel 1.

Tabel 1. Kriteria Validitas Modul

\begin{tabular}{ccl} 
No & $\begin{array}{c}\text { Kriteria Validitas (Data Uji } \\
\text { Kompetensi) }\end{array}$ & \multicolumn{1}{c}{ Tingkat Validitas } \\
\hline 1 & $85,01 \%-100,00 \%$ & Sangat valid, atau dapat digunakan tanpa revisi \\
\hline 2 & $70,01 \%-85,00 \%$ & Valid, atau dapat digunakan namun perlu direvisi kecil \\
\hline 3 & $50,01 \%-70,00 \%$ & $\begin{array}{l}\text { Kurang valid, disarankan karena tidak dipergunakan } \\
\text { karena perlu revisi besar }\end{array}$ \\
\hline 4 & $01,00 \%-50,00 \%$ & Tidak valid, atau tidak boleh dipergunakan \\
\hline
\end{tabular}


Pengembangan Modul Berbasis ...

Efektivitas Modul Pembelejaran

Ukuran suatu efektivitas modul IPA dengan membandingkan antara nilai $\mathrm{O}_{1}$ dan $\mathrm{O}_{2}$. Modul IPA dikatakan efektif apabila nilai $\mathrm{O}_{2}$ lebih besar dari nilai $\mathrm{O}_{1}$. Pengujian produk yang dilakukan oleh peneliti menggunakan desain One Group Pretest-Posttest. Uji awal atau pretest dilakukan di awal sebelum diberi perlakuan. Sehingga hasil dari diberi perlakuan dapat diketahui lebih akurat dan dibandingkan dengan keadaan setelah diberi perlakuan. Gambaran desain untuk penelitian One Group PretestPosttest pada Gambar 1.

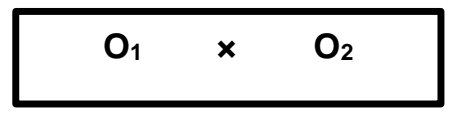

Keterangan:

X : Perlakuan (media game edukasi Quizizz) yang diberikan

$O \quad$ : Nilai tes setelah diberi perlakuan

Gambar 1. Desain Penelitian (Sugiyono, 2012)

Keterangan:

$\mathrm{O}_{1}=$ nilai pretest (sebelum diberi perlakuan)

$\mathrm{O}_{2}=$ nilai posttest (sesudah diberi perlakuan)

Efektivitas modul pembelajaran dianalisis secara kuntitatif berdasarkan hasil pretest dan posttest siswa menggunakan Persamaan 2. Kemudian disesuaikan dengan kriteria N-gain pada Tabel 2 (Hake, 1998).

$$
\text { Normalized Gain }(G)=\frac{\text { skor posttest }- \text { skorpretest }}{\text { skor maksimum }- \text { skor minimum }}
$$

Tabel 2. Kriteria Normalized Gain

\begin{tabular}{cc}
\hline Nilai N-Gain & Kriteria \\
\hline$<\mathrm{G}>>0.70$ & Tinggi \\
\hline $0.30 \leq<\mathrm{G}>\geq 0.70$ & Sedang \\
\hline$<\mathrm{G}><0.30$ & Rendah \\
\hline
\end{tabular}

\section{Respon Siswa}

Tanggapan siswa terhadap modul dituangkan dalam bentuk pemberian skor terhadap pernyataan yang terlampir dalam angket. Masing-masing aspek dinilai menggunkan skala likert, yaitu skor 1 hingga 4 (dengan keterangan 1: tidak baik; 2: kurang baik; 3: baik; 4: sangat baik). Hasil skor yang diperoleh dihitung menggunakan persentase perolehan skor respon siswa pada Persamaan 3. Kemudian disesuaikan dengan kriteria respon siswa yang ditunjukkan pada Tabel 3 (Umar, 2011).

$$
\text { Nilai rata }- \text { rata }=\frac{\sum(\text { frekuensi } \times \text { bobot })}{\sum \text { populasi }(n)}
$$

Tabel 3. Kriteria Respon Siswa

\begin{tabular}{cc}
\hline Interval Skor & Kriteria \\
\hline $1,00-1,75$ & Sangat tidak baik \\
\hline $1,76-2,50$ & Tidak baik \\
\hline $2,51-3,25$ & Baik \\
\hline $3,26-4,00$ & Sangat Baik
\end{tabular}

Interval skor tersebut diperoleh dengan menggunakan Persamaan 4 melalui tahap sebagai berikut:

Skor minimum $=1$ 
Skor maksimum $=4$

$$
\text { Lebar skor }=\frac{\text { skor maksimum }- \text { skor minimum }}{\text { Skor maksimum }}=\frac{4-1}{4}=0,75
$$

\section{HASIL DAN PEMBAHASAN}

Data hasil dari penelitian ini membahas tentang bagaimana validitas modul IPA berbasis STEM, efektivitas modul IPA berbasis STEM okok bahasan alat-alat optik serta hasil respon siswa terhadap modul IPA berbasis STEM. Modul yang dikembangkan divalidasi melalui lembar validasi yang meliputi indokator atau aspek validasi sebagai berikut: (1) relevansi; (2) keakurata; (3) pembelajaran berpusat pada siswa; dan (4) kebahasaan. Berdasarkan hasil penilaian oleh validator ahli, modul IPA berbasis STEM materi alat-alat optik memperoleh skor seperti yang ditunjukkan pada Tabel 4. Rata-rata total dari validator ahli menunjukkan angkat 3.7 atau menunjukkan persentase sebesar $92.5 \%$ yang berarti modul IPA berbasis STEM materi alat-alat optik dalam kategori sangat valid dan modul dapat digunakan tanpa revisi (Akbar, 2013: 41).

Tabel 4. Data hasil validasi ahli

\begin{tabular}{lcccccc}
\hline No & $\begin{array}{c}\text { Total skor } \\
\text { validator } \mathbf{1}\end{array}$ & $\begin{array}{c}\text { Total skor } \\
\text { validator } \mathbf{2}\end{array}$ & $\begin{array}{c}\text { Total skor } \\
\text { validator } \mathbf{3}\end{array}$ & $\begin{array}{c}\text { Rata-rata } \\
\text { total }\end{array}$ & $\begin{array}{c}\text { Validitas } \\
\text { ahli (\%) }\end{array}$ & Kategori \\
\hline 1 & 4.00 & 3.6 & 3.8 & 3.7 & 92.5 & $\begin{array}{c}\text { Sangat } \\
\text { valid }\end{array}$ \\
\hline
\end{tabular}

Data keefektifan modul diperoleh melalui tahap penilaian produk. Tahap penilaian produk merupakan penilaian terhadap modul IPA berbasisi STEM materi alat-alat optik yang telah valid dan disempurnakan. Tahap penilaian dilakukan dengan mengujikan modul yang telah valid untuk uji coba lapangan. Uji coba lapangan dilakukan kepada siswa kelas VIII IPA B MTsN 4 Banyuwangi. Subjek penelitian berjumlah 32 siswa. Siswa diberi pretest sebelum mengikuti pembelajaran menggunakan modul IPA berbasis STEM yang dikembangkan. Pretest ini bertujuan untuk mengetahui pengetahuan awal siswa tentang materi alat optik dan juga sebagai pembanding nilai posttest yang dilakukan setelah seluruh materi selesai dipelajari. Kedua jenis nilai tersebut kemudian diolah untuk menentukan tingkat efektivitas modul menggunakan $\mathrm{N}$-gain. Hasil nilai pretest dan posttest secara terperinci dapat dilihat pada Tabel 5.

Tabel 5. Data hasil nilai pretest dan posttest siswa

\begin{tabular}{lc}
\multicolumn{1}{c}{ Test } & Skor \\
\hline Rata-rata nilai pretest & 32.56 \\
\hline Nilai tertinggi pretest & 56 \\
\hline Nilai terendah pretest & 10 \\
\hline Rata-rata nilai posttest & 74.6 \\
\hline Nilai tertinggi posttest & 90 \\
\hline Nilai terendah posttest & 48 \\
\hline N-gain & 0.42 \\
\hline
\end{tabular}

Data tersebut menunjukkan bahwa nilai $\mathrm{N}$-gain yang diperoleh adalah 0.42 dan termasuk dalam kategori sedang berdasarkan kriteria keefektifan modul (Hake, 1998). Hasil tersebut menunjukkan peningkatan hasil belajar siswa antara sebelum dan sesudah menggunakan modul IPA berbasis STEM pokok bahasan alat-alat optik. Jadi, modul IPA berbasis STEM cukup efektif untuk digunakan dalam pembelajaran.

Setelah menganalisis keefektifan modul, siswa memberikan respon terhadap modul yang telah digunakan dalam pembelajaran dengan mengisi angket respon siswa. Angket tersebut diberikan pada pertemuan terakhir setelah pembelajaran. Data hasil respon siswa terhadap modul IPA berbasis STEM secara ringkas dapat diamati pada Tabel 6. 
Tabel 6. Data hasil respon siswa

\begin{tabular}{ccc}
\hline Aspek & Rata-rata skor & Kriteria \\
\hline Pernyataan positif & 3.27 & Baik \\
\hline Pernyataan negatif & 1.82 & Tidak Baik \\
\hline
\end{tabular}

Hasil skor rata tersebut dicocokkan atau ditafsirkan ke dalam kriteria respon siswa, sehingga diperoleh hasil pernyataan positif dengan rata-rata skor 3.27 termasuk dalam kriteria baik dan pernyataan negatif dengan rat-rata 1.82 termasuk dalam kategori tidak baik.

\section{PENUTUP}

Modul IPA berbasis STEM pokok bahasan alat-alat optik memperoleh skor validasi 3.7 atau menunjukkan persentase sebesar $92.5 \%$ dan termasuk dalam kategori valid yang berarti modul tersebut layak untuk digunakan dalam pembelajaran. Modul IPA berbasis STEM juga memperoleh nilai $\mathrm{N}$-gain 0.42 atau dalam kategori sedang yang berarti modul tersebut efektif digunakan dalam pembelajaran. Respon siswa terhadap modul IPA berbasis STEM menunjukkan jika skor ratarata pernyataan positif sebesar 3.27 yang termasuk dalam kategori baik dan pernyataan negative sebesar 1.82 yang termasuk dalam kategori tidak baik.

\section{DAFTAR PUSTAKA}

Akbar, S. (2013). Instrumen Perangkat Pembelajaran. Bandung: PT. Remaja Rosdakarya.

Arikunto, S. (2006). Prosedur Penelitian Suatu Pendekatan Parktek. Jakarta: Rineka Cipta.

Darmaji., A. Kuriawan, dan A. Suryani. (2019). Effectiveness of Basic Physics II Practicum Guideline Based on Science Process Skills. Journal Physics Education. 4(1): 1-7.

Hake, R. R. (1998). Interactiv Engangement vs Traditional Methods: A-Six Thousand-student Survey of Mathematics Test Data for Introductory Physics Course. American Journal of Physics. 66 (10: 1.

Kuswanto. J. (2019). Pengembangan Modul Interaktif Pada Mata Pelajaran IPA Terpadu Kelas VIII. Media Infotama. 15 (2): 51-55. ISSN 1858 - 2680.

Maslahah, W., dan L. Rofiah (2019). Pengembangan Bahan Ajar (Modul) Sejarah Indonesia Berbasis Candi-Candi di Blitar Untuk Meningkatkan Kesadaran Sejarah. Agastya. 9 (1): 32-42.

Mufarrikoh, Z (2020). Statistik Pendidikan (Konsep Sampling dan Uji Hipotesis). Surabaya: CV. Jakad Media Publishing.

Nieveen, N. (2006). Formative Evaluation in Educational Design Research. Dalam An Introduction to Educational Design Research. Editor T. Plomp, dan N. Nieveen. Netzodruk: Enschede Netherlands.

Puskur, Balitbang. (2007). Panduan Pengembangan Pembelajaran IPA Terpadu. Jakarta: Depdiknas.

Pohan, A. E. (2020). Konsep Pembelajaran Daring Berbasis Pendekatan Ilmiah. Purwodadi: CV Sarnu Untung.

Retnowati et al. (2020). The STEM Approach: The Development of Rectangular Module to Improve Critical Thinking Skill. Internationl Online Journal of Education and Teaching (IOJET). Vol 7 (1).

Rosa, F. O. (2015). Pengembangan Modul Pembelajaran IPA SMP Pada Materi Tekanan Berbasis Keterampilan Proses Sains. Jurnal Pendidikan Fisika. 3(1): 49-63.

Selley, M., S. Alan, dan Celik, I. (2016). Intenational Cenference on Education in Mathematics, Science \& Technology. Journal of Educational and Science Technology. 1: 19-22.

Thibaut et al. (2018). Intregated STEM Education: A Systematic Review of Intructional Practices in Secondary Education: Journal of STEM Education. Vol 3 (1). 